Rochester Institute of Technology

RIT Scholar Works

Presentations and other scholarship

Faculty \& Staff Scholarship

5-1-2019

\title{
Shear Strength of Deteriorated Steel Girders in Multi-Girder Bridges
}

Amanda Bao

Rochester Institute of Technology

Caleb Guillaume

Alana Moraes

Follow this and additional works at: https://scholarworks.rit.edu/other

\section{Recommended Citation}

Bao, Amanda; Guillaume, Caleb; and Moraes, Alana, "Shear Strength of Deteriorated Steel Girders in MultiGirder Bridges" (2019). Accessed from

https://scholarworks.rit.edu/other/969

This Conference Proceeding is brought to you for free and open access by the Faculty \& Staff Scholarship at RIT Scholar Works. It has been accepted for inclusion in Presentations and other scholarship by an authorized administrator of RIT Scholar Works. For more information, please contact ritscholarworks@rit.edu. 


\title{
SHEAR STRENGTH OF DETERIORATED STEEL GIRDERS IN MULTI-GIRDER BRIDGES
}

\author{
AMANDA BAO ${ }^{1}, \mathrm{PhD}, \mathrm{PE}, \mathrm{CALEB}$ GUILLAUME and ALANA MORAES \\ Civil Engineering Technology, Rochester Institute of Technology, USA \\ ${ }^{1}$ Corresponding author, 78 Lomb Memorial Drive, ENT-3154, Rochester, NY 14623, USA. \\ axbite@ rit.edu
}

Bridge deterioration is mainly caused by repeated traffic loads and adverse environmental exposure. According to the 2017 American Society of Civil Engineers' infrastructure report card, more than 9\% of the bridges in the United States were labeled structurally deficient. For steel bridges, the most dominant deterioration form is corrosion, which is characterized by the metal area loss resulting in structural capacity reduction. Corrosion is very common in steel multi-girder bridges because of moisture exposure, leakage through bridge joints as well as the frequent use of deicing detergents during the winter season in cold regions. Over the years, the rust can be serious enough to disconnect the web from the flanges of the girder, which poses significant concerns for load capacity especially at girder ends. This research studies shear strength loss in deteriorated steel multi-girder bridges by 3-D finite element models built in ABAQUS. Our analysis is focused on web area loss and web thinning due to corrosion, and their consequences for shear and web buckling capacity reduction. Area loss will be modeled by removing materials from the web, and web thinning will be simulated by reducing the web thickness. The numerical models resemble real steel corrosion forms by changing the shape, size and location of the area loss. A load rating method will be proposed based on the analyses.

Key words: bridge, deterioration, girder, finite element

\section{INTRODUCTION}

According to the ASCE 2017 Infrastructure Report Card, more than 9\% of bridges in the United States were labeled structurally deficient, indicating some degree of deterioration of structural elements. ${ }^{[5]}$ In cold regions, frequent use of deicing chemicals in the winter season and bridge joint leakage are the main causes of corrosion in steel girder bridges. Figure 1 shows the typical girder corrosion forms. Excessive rust accumulation over the years can be serious enough to disconnect the girder web from the flanges, which poses significant concerns for structural capacity especially at girder ends. $[4,6,7,8,10,11]$
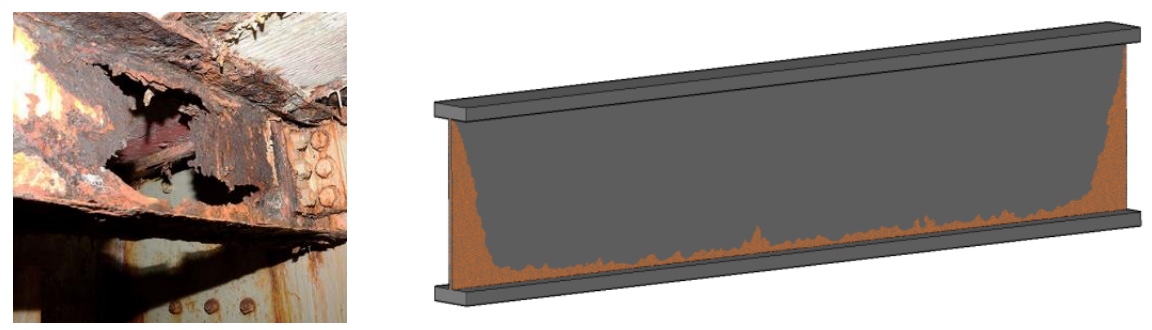

Figure 1: Typical Steel Girder Corrosion at Web and Flange ${ }^{[6]}$. 
In this study, the residual shear strength of corroded steel girder bridges is evaluated by 3-D finite element modeling. Our analysis and testing are focused on the effects of web area loss and web thinning on shear and web buckling capacity reduction.

\section{3D FINITE ELEMENT MODELING}

It is costly to perform full scale physical experiments on bridges. Finite element modeling has been used for decades to do research on large scale structures. In this research, ABAQUS is used as a tool to analyze the mechanical behaviors of deteriorated girders. ${ }^{[1]} 3 \mathrm{D}$ finite element models are set up to study web buckling and shear capacity of corroded girders. The load cases and the controlling forces are selected according to the load combinations specified in AASHTO LRFD Bridge Design Specifications. ${ }^{[2,9]}$ Translation and rotation at the girder ends are modeled properly to simulate the support conditions. Corrosive area loss is simulated by removing part of web area, and web thinning is modeled by reducing the web thickness uniformly. ${ }^{[6]}$ Web thinning due to rust mainly reduces the girder's shear strength and web buckling strength. The structural capacity of the deteriorated girders is analyzed.

The prototype bridge is a simple span I-Plate steel girder bridge with a cast-in-place concrete deck. The span length of the bridge is 130 feet. The overall width of the bridge is 98 feet, and the bridge carries 6 lanes of traffic. The design live load on the bridge is the typical AASHTO HL-93 Live Load. The cast-in-place deck is 9 inches thick. The bridge framing has 10 girder lines with 10 feet girder spacing. Figure 2 and Figure 3 shows the bridge elevation and the bridge typical section, respectively.

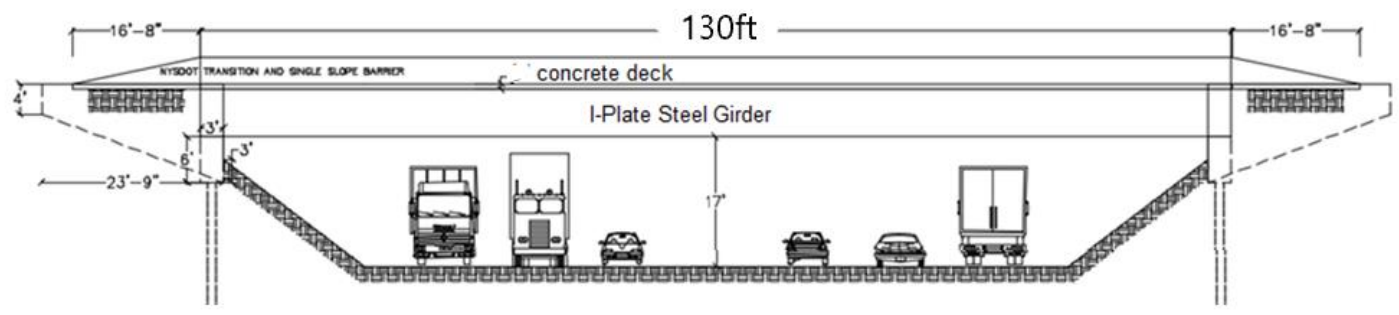

Figure 2: Bridge Elevation.

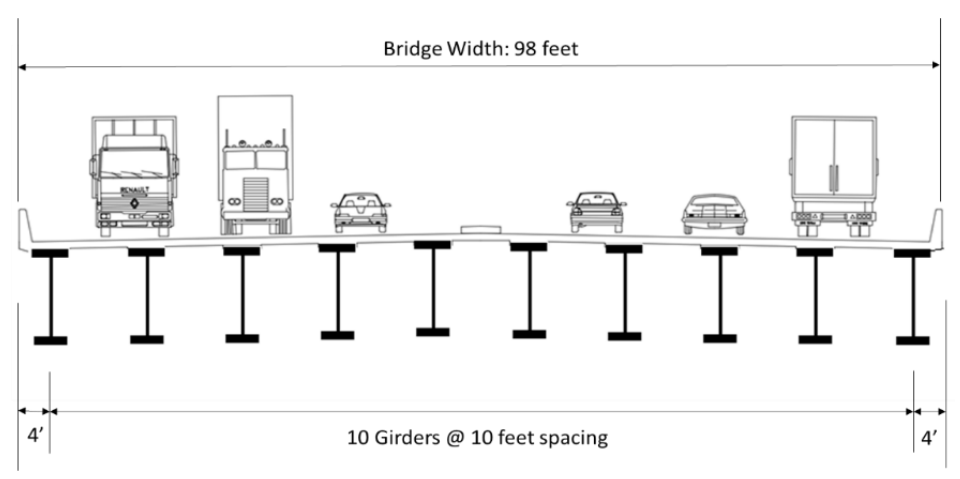

Figure 3: Bridge Typical Section. 
The I-plate steel girder has a top flange of 12 inches wide and 2 inches thick, a web of 48 inches deep and $1 / 2$ inch thick and a bottom flange of 12 inches wide and 2 inches thick. The overall depth of the steel girder is 52 inches. The length of the girder end model is 100 inches. The boundary conditions are pinned at one end of the top and bottom flanges to simulate the real girder end embedded into the abutment diaphragm. The pinned support is 6 inches long on both the top and the bottom flanges to represent the real bearing length of a simple span girder. The other end is free in vertical movement but restricts horizontal movement along the girder line. The girder end finite element model in ABAQUS is shown in Figure 4. The steel girder material uses Grade 50 steel with a yield strength of $50 \mathrm{ksi}$, and an ultimate strength of $65 \mathrm{ksi}$. The steel has an elastic modulus of $29,000 \mathrm{ksi}$ and a Poisson's ratio of $0.30 .^{[3]}$
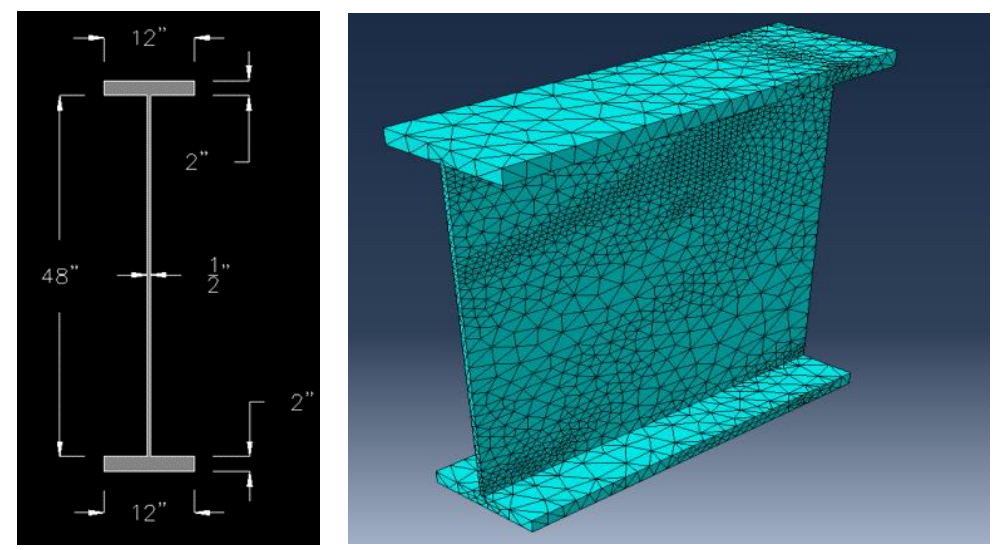

Figure 4: Girder End FEM Model in ABAQUS.

\section{MODELING RESULTS}

A typical interior girder is used for calculating the shear force at the girder end. The unfactored non-composite and composite dead load (DC) on the girder is $2.0 \mathrm{kip} / \mathrm{ft}$, and the unfactored wearing surface (DW) on the girder is $0.40 \mathrm{kip} / \mathrm{ft}$. The live load (LL) on the girder is AASHTO HL-93 live load, the dynamic impact factor of the design truck HS20-44 is 1.33, and the live load distribution factor for shear is 0.952 , which is calculated according to AASHTO LRFD Bridge Design Specifications as shown in Equation 1. ${ }^{[2]}$

Live load distribution factor for shear $=$

$$
\operatorname{Max}\left\{\begin{array}{c}
\text { one lane loaded: } 0.36+\frac{s}{25}=0.36+\frac{10}{25}=0.760 \\
\geq 2 \text { lanes loaded: } 0.2+\frac{s}{12}-\left(\frac{s}{35}\right)^{2}=0.2+\frac{10}{12}-\left(\frac{10}{35}\right)^{2}=\mathbf{0 . 9 5 2}
\end{array}\right.
$$

where $\mathrm{S}=$ girder spacing.

The maximum design shear force at the girder end is obtained by Strength I load combination specified in Equation 2 according to AASHTO LRFD Bridge Design Specifications. ${ }^{[2]}$

$$
\text { Strength I Load Combination: } 1.25 D C+1.5 D W+1.75 L L \quad \text { (Equation 2) }
$$


Figure 5 shows the load diagram for the single girder analysis. The calculated design shear force according to the single girder analysis is 420 kips at the girder end.

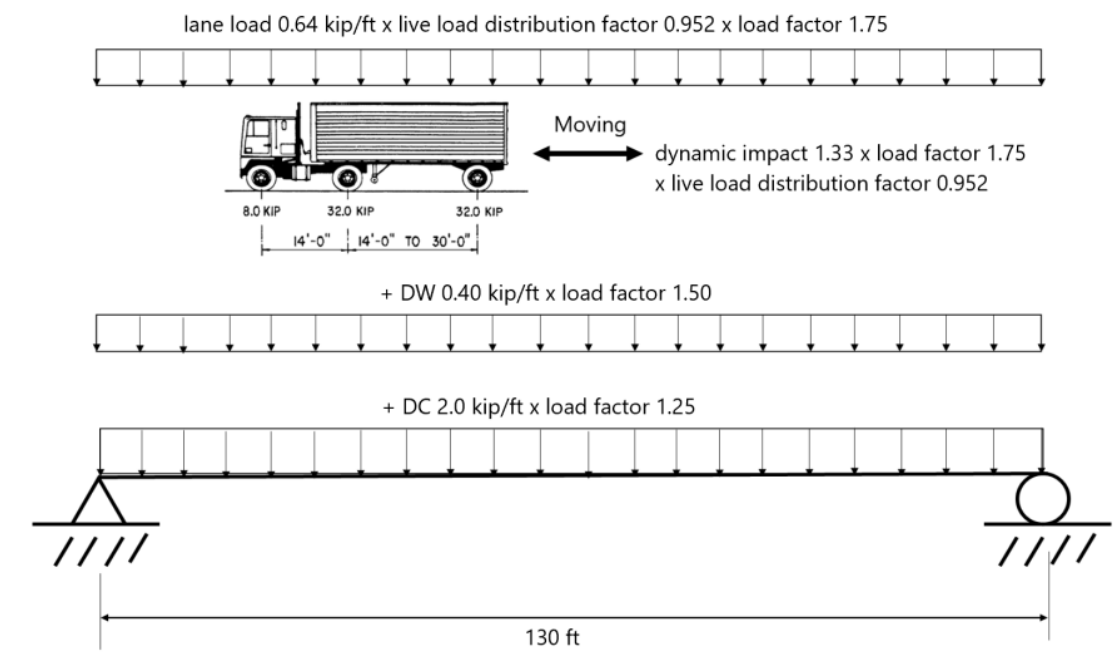

Figure 5: Single Girder Analysis.

\section{RESULTS}

The original web size is 48 inches deep by $1 / 2$ inch thick. The web thinning due to rust is modeled by reducing the web thickness in the section geometry input. The web bucking capacity of the intact web is 678 kips according to the ABAQUS analysis. The web bucking capacity vs. web thinning is plotted in Figure 6. The web thicknesses in the plot are 0.50 inch (original thickness), 0.475 inch (5\% thickness reduction), 0.45 inch (10\% thickness reduction), 0.425 inch (15\% thickness reduction), 0.40 inch (20\% thickness reduction) and 0.375 inch (25\% thickness reduction), respectively.

The area loss due to corrosion is modeled by removing portions of the web. In this paper, the shape of the area loss is modeled by a rectangular hole with the longer side parallel to girder line. The results of web buckling capacity vs. sizes of area loss are shown in Figure 7 and Figure 8. The effect of varying hole location on the web buckling strength is illustrated in Figure 9. The area loss size used in Figure 9 is 6"x18" = 108 in $^{2}$.
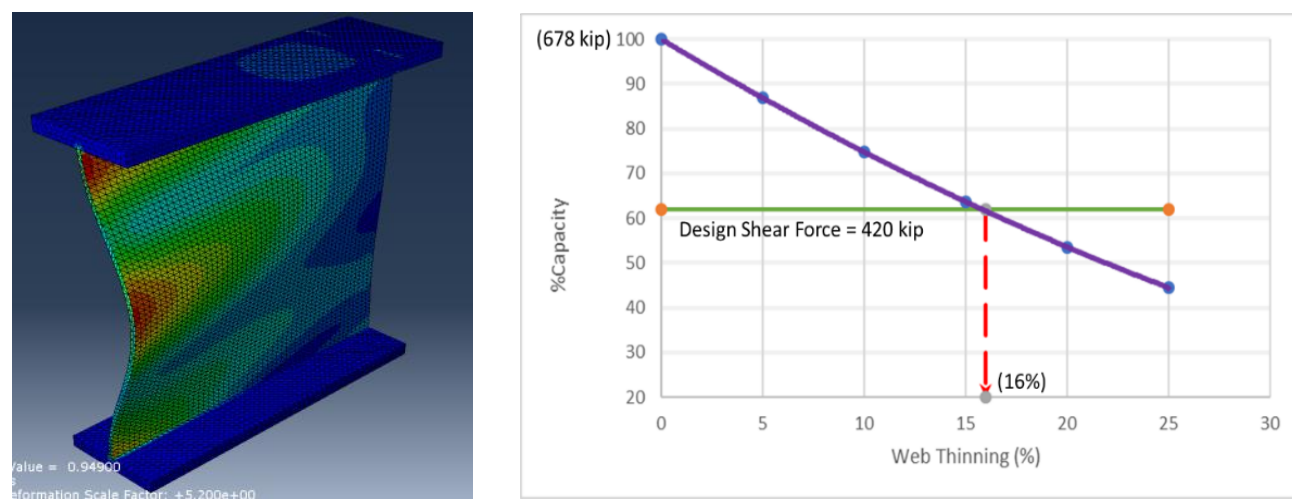

Figure 6: Web Buckling Capacity vs. Web Thinning. 


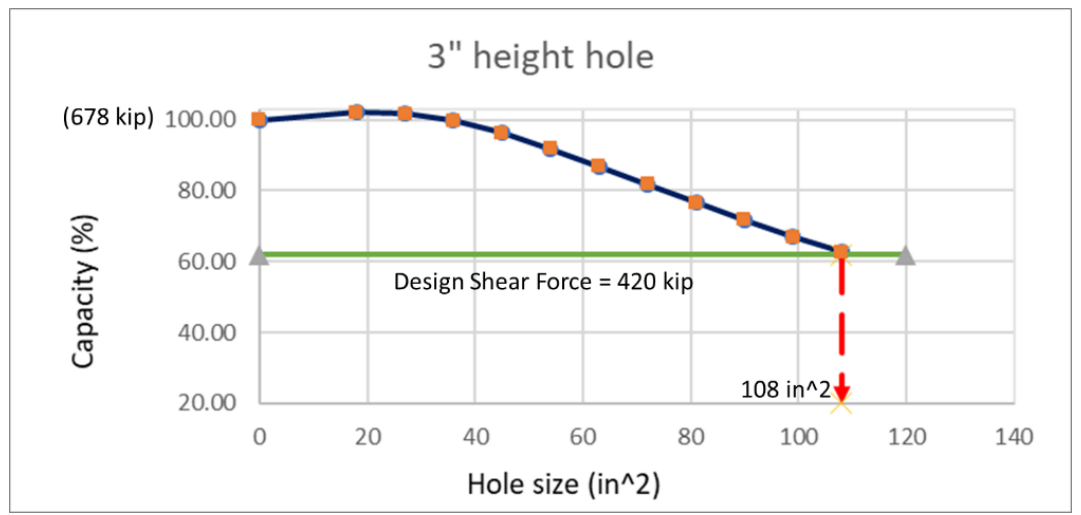

Figure 7: Web Buckling Capacity vs. Area Loss - Hole Height 3”.

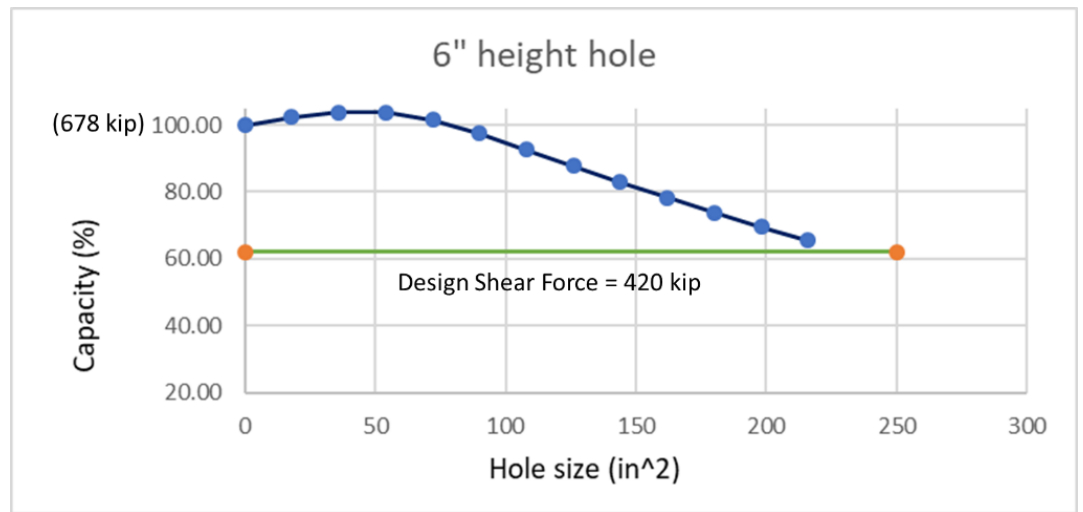

Figure 8: Web Buckling Capacity vs. Area Loss - Hole Height 6”.

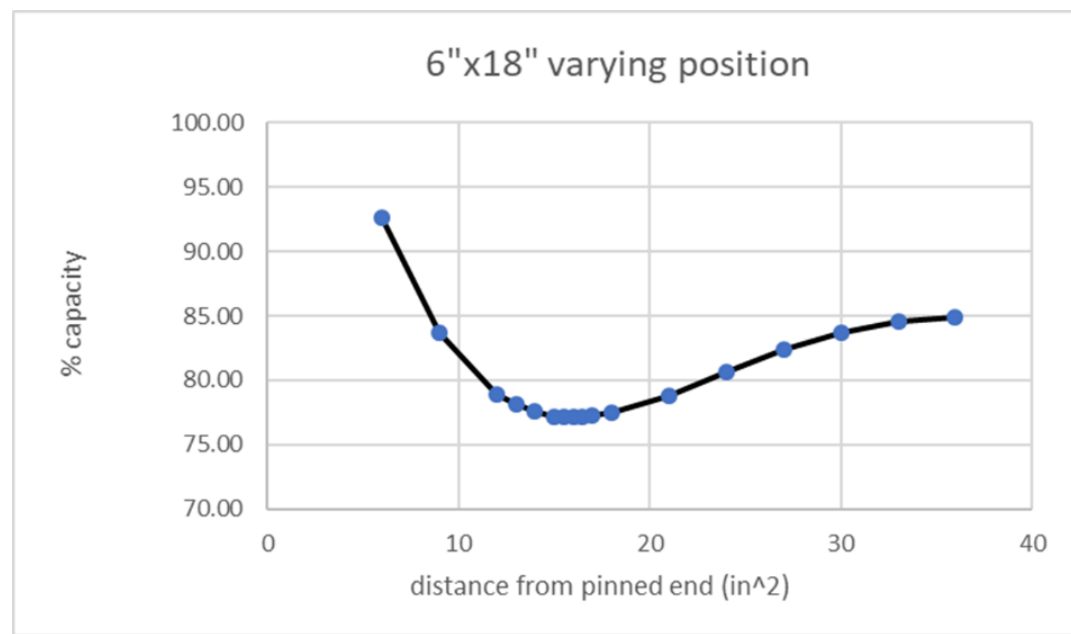

Figure 9: Web Buckling Capacity vs. Hole Location - Hole Size 6"x18".

\section{CONCLUSIONS}

Common corrosion types including web thinning and web area loss and their effects on the structural capacity of deteriorated girders are investigated in this paper. 
According to the results of 3D finite element analyses using ABAQUS, the conclusions of this research are:

1) Web thinning due to corrosion has a significant effect on girder shear and web buckling strength. Development of extensive rust can dramatically reduce the girder's structural capacity. $10 \%$ reduction in web effective thickness may result in $25 \%$ or more buckling strength and $20 \%$ reduction of web thickness may lead to $50 \%$ structural capacity loss due to decreasing effective web cross sectional area as well as increasing width to thickness ratio of the web.

2) Figure 7 and Figure 8 show consistently that the larger size of area loss, the lower the structural capacity. The strength may drop below the girder design load when the size of hole keeps growing, which represents structural deficiency.

3) Comparing Figure 7 with Figure 8, we can find that when extending area loss in the direction parallel to the girder line, the structural capacity decreases at a higher rate than extending area loss in the direction parallel to the web depth.

4) Figure 9 shows that the location of the area loss significantly affects the structural capacity, when the hole starts about $1 / 3$ of the web depth from the beam end support, the structural capacity reaches its lowest point.

\section{Acknowledgement}

This study is supported by Western New York Association for Bridge Construction and Design Research Grant (2017-2018) and Rochester Institute of Technology College of Applied Science and Technology Scholarship Incentive Grant (2017).

\section{References}

[1] ABAQUS/CAE User's Guide, 2016.

[2] American Association of State Highway and Transportation Officials, "AASHTO LRFD Bridge Design Specifications", $7^{\text {th }}$ Edition, 2016

[3] American Institute of Steel Construction, Steel Construction Manual, 15 $5^{\text {th }}$ Edition, 2017.

[4] Al Badran, M.S., "Structural Reliability Analysis of Corroded Steel Girder Bridge", Master Thesis, University of Nebraska-Lincoln, 2013.

[5] American Society of Civil Engineers (ASCE) 2017 Infrastructure Report Card, 2017.

[6] Bao, A., Gulasey, M., Guillaume, C., Levitova, N., Moraes, A. and Satter, C., "Structural Capacity Analysis of Corroded Steel Girder Bridges", Proceedings of the 3rd International Conference on Civil, Structural and Transportation Engineering, Paper ID 118, Niagara Falls, Canada, June 10-12, 2018.

[7] Kayser, J., \& Nowak, A., "Reliability of Corroded Steel Girder Bridges", Elsevier Science Publishers: Structural Safety, Vol 6, 1989.

[8] Kulicki, J., Prucz, Z., Sorgenfrei, D., Mertz, D., \& Young, W., "Guidelines for Evaluating Corrosion Effect in Existing Steel Bridges", National Cooperative Highway Research Program, Report 333, 1990.

[9] NYSDOT Bridge Manual, 2017.

[10] Sharifi, Y., "Residual Web Bearing Capacity of Corroded Steel Beams", Advanced Steel Construction, Vol. 8, No. 3, 2012, pp 242-255.

[11] Van de Lindt, J., \& Ahlborn, T., "Development of Steel Beam End Deterioration Guidelines", Michigan Technological University, 2005 